\title{
The role of affect in management decisions: A systematic review
}

\author{
Matteo Cristofaro \\ University of Rome "Tor Vergata”, Via Columbia, 200133 Rome, Italy
}

\section{A R T I C L E I N F O}

\section{Article history:}

Received 10 September 2018

Received in revised form

15 November 2018

Accepted 11 December 2018

Available online $\mathrm{xxx}$

\section{Keywords:}

Decision making

Affect

Emotions

Cognition

Co-evolution

Literature review

\begin{abstract}
A B S T R A C T
Since the birth of the bounded rationality concept, scholars have been increasingly involved in identifying how management decisions are made; identifying the role played by affect has been a crucial part of the mission. However, despite the recent hype in the number of researches published on this theme that has been carried into the new definition of bounded emotionality - a systematisation of those contributions able to identify the different functions played by different affective states is still lacking. This review article aims to fill this gap. The implemented methodology is the Systematic Literature Review. A total of 123 articles have been analysed through a descriptive as well as a thematic approach; the latter has followed a mixed inductive-deductive method. Results of the thematic analysis show six distinct functions played by affect in management decisions, offering an updated framework. The proposed model explains how affect influences management decisions on the basis of co-evolutionary mechanisms. The value of this work lies in offering a model of the functions played by affect in management decisions, which is pivotal for designing a firm's informed decision architecture. Furthermore, it is the first review on this theme to adopt a scientific approach and an established psychological framework for, respectively, the systematisation and analysis of the contributions.
\end{abstract}

(c) 2018 Elsevier Ltd. All rights reserved.

\section{Introduction}

Herbert Simon (1947) stated that individuals cannot ever reach optimal decisions because of their innate cognitive and biological limitations, but later declared in order to have anything like a complete theory of human rationality, we have to understand what role emotion plays in it' (1983; p. 29). Since then, scholars of different scientific domains have shown a growing commitment to a better understanding of the causes of deviation from canonical rationality (Cristofaro, 2017), progressively focusing their attention on the role of affect (or affective states) - intended as the 'emotion or subjectively experienced feeling, such as happiness, sadness, fear, or anger' (Colman, 2003, p. 14) - in shaping decision-making activities (e.g. Damasio, 1994; Forgas \& George, 2001). In particular, during the last 30 years, scholars have been trying to integrate the affect perspective into the current view of organisations and their processes (Barsade \& Gibson, 2007; Barsade, Ward, Turner, \& Sonnenfeld, 2000; Bell, 1982), leading to a so-called affect revolution. Thanks to this strong effort, today we can state that emotions, mood and temperament influence management decisions, as proved by several empirical works (e.g. Ashkanasy, Humphrey, \&

E-mail address: matteo.cristofaro@uniroma2.it.
Huy, 2017; Barsade, 2002; Haynie, Flynn, \& Mauldin, 2017; Kouamé, Oliver, \& Poisson-de-Haro, 2015; Walsh, 2018; Yang \& Kelly, 2016) among which it has been demonstrated, for example, that affect seems to give direction when making management decisions on service innovation processes (Von Koskull, Strandvik, \& Tronvoll, 2016).

However, recent review works on the role of affective states have focused on other management sub-fields, such as entrepreneurial cognition (e.g. Baron, 2009; Delgado-Garcia, De Quevedo Puente, \& Blanco Mazagatos, 2015), where articles have been analysed mainly according to the entrepreneurial process stages (e.g. opportunity recognition, opportunity evaluation, etc.), leadership (Gooty, Connelly, Grif, \& Gupta, 2010), where articles have been thematised according to the leader-follower affective relationship and its effects on job performance, and negotiation (Methasani, Gaspar, \& Barry, 2017), where authors have focused their attention only on the effect of emotions on social interactions. Yet, psychology-based review works have highlighted the different functions played by affect in decision-making activities (e.g. Lerner, Li, Valdesolo, \& Kassam, 2013; Loewenstein \& Lerner, 2003), but their scope has been limited to the individual decision-making activity, thus neither considering the collective decision making nor the escalation from individual to group decision making - which are common dynamics at the basis of management decisions in 
organisations (Cyert \& March 1963; Powell, Lovallo, \& Fox, 2011).

Therefore, a first systematisation of the produced contributions to the role of affect in management decisions (thus the decisionmaking activities made at the low-, middle- and topmanagement levels; Koontz, O'Donnell, \& E Weihrich, 1980) is pivotal and still lacking; this absence means scholars are looking at this phenomenon from similar points of view but leaving important gaps unexplored while producing duplicates. For example, Spering, Wagener, and Funke (2005) and Blay, Kadous, and Sawers (2012) analogously found that decision makers in a negative mood are more inclined to continue and develop their search strategy than executives in a positive mood. Yet, the need for a summarisation is even more important if looking at the effect of different affective states on management decisions, which are sometimes argued to be positive (O'Connell, 2007) and other times negative (Gino, 2015), mainly through not considering that there are different mechanisms by which affective states can differently influence the same management decision.

This Systematic Literature Review (SLR) systematises 123 contributions related to the role of affect in management decisions. In doing so, it aims to: $i$ ) uncover the main themes in this area, especially by looking at the most recent advancements made in the literature, and ii) propose an updated model for the understanding of how management decisions are influenced by managers' and others' affective states.

The results of this work make a case for the adoption of a coevolutionary approach. In particular, this lens is needed because it rests on some important assumptions i.e. thinking in circles (Weick, 1969), multi-level influences (Breslin, 2016), and units of analysis connected by interdependence and reciprocal feedbacks (Lewin \& Volberda, 2005). These principles can help understand how a management decision is affected by managers' and others' (individuals or groups positioned at the same or different hierarchical level) affective states. This theoretical lens has been successfully advanced for explaining other important management decision mechanisms, e.g. biased management choices (Abatecola, 2014b; Abatecola, Caputo, \& Cristofaro, 2018).

Thanks to this interpretation, the understanding provided contributes to drawing the psychological architecture of the firm (Powell et al., 2011), thus 'the design of decision processes that capture what we know about cognitive and social psychology' (Sibony, Lovallo, \& Powell, 2017, p. 6). This is a fundamental step for improving decision processes at the organizational level.

The remainder of this work is as follows. First, the main theoretical elements that guide this review are offered to European Management Journal readers. Second, the methodological steps of the SLR are explained. Third, descriptive evidence from sample articles is shown. Fourth, results of the thematic analysis are reported. Fifth, an updated framework describing the role of affective states in management decisions and the major challenges for future research are presented.

\section{Theoretical background}

\subsection{Affect and decision making}

According to Forgas (1995), the word 'affect' is an umbrella term that covers different affective states, among which the main ones are 'moods' and 'emotions'. Moods can be considered as a lowintensive and enduring affective state (e.g. feeling down) that does not come from the affective reaction to a specific object, whereas emotions are more distinguishable because they are caused by the affective reaction to a situation. Moods and emotions are 'affective states' stricto sensu, whereas the stable individual differences in experiencing positive or negative affects (e.g. always being happy) are more properly defined as 'affective traits' or 'temperament' (see the specific definitions of Forgas \& George, 2001). However, this has also been included under the general label of affective states by Forgas and George (2001) and Lerner et al. (2013).

Because of these subtle differences, some conceptual and literature reviews in the psychological domain have recognised the different functions played by affect in individual decision-making activities (e.g. Lerner et al., 2013; Loewenstein \& Lerner, 2003), thus: $i$ ) affective states shape decisions by the content of thought (e.g. fearful people tend to see greater risk in an option than less fearful individuals), ii) affective states shape the depth of thought (e.g. being in a positive mood lets individuals rely on cognitive heuristics), iii) affect shapes decision making by goal activation (e.g. being angry pushes individuals to change a situation) and iv) affect influences interpersonal decision making (e.g. showing anger requires adjustments in bargaining).

However, these psychological functions do not properly take into account the advancements for which affect is considered, respectively, to influence group decisions (Casciaro \& Lobo, 2008), and to work together with the evolving environment in which the situation takes action (Hillebrandt \& Barclay, 2017).

\subsection{Co-evolutionary approach}

The organizational evolution research area is concerned with the study of the competitive relationship between organisations and their external environment through the use of biological metaphors (Abatecola, 2014b). The co-evolutionary approach, which lies within the above-outlined domain, interprets the organizational-environment relationship as dialectical, thus organizational outcomes come from the different configurations of power relationships between those forces exerted by organisations and by the environment (Benson, 1977; Cafferata, 2016). Coevolutionary scholars partially adopt the biological interpretation, in contrast to the commonly labelled 'Generalized Darwinists' (Abatecola, 2014b), for the study of organisations because of the human intentionality issue, thus the intentionality of firms' top decision makers in determining organizational adaptation (Murmann, Aldrich, Levinthal, \& Winter, 2003): managers' decisions concurrently affect, with the environment, organizational performance. This important point on the basis of the coevolutionary approach derives from Weick (1969), for whom the reality faced by firms is not objectively existent but is enacted by people operating within organisations (at both individual and group levels) on the basis of their specific background, experience and, thus, evolving learning mechanisms (this assumption is also the basis of Hambrick and Mason's (1984) Upper Echelons Theory).

Furthermore, Weick (1969) states that the relationship between people and their external world, physical and/or social, emerges as circular, as their enactment of the external reality retroactively conditions their evolving behaviour; this is the thinking in circles assumption of the co-evolutionary approach. Also, another important assumption of the co-evolutionary approach is the multi-level logic, thus the influences occurring at different analysis levels: between organisations and their external environment (macrolevel), between sector and firm (meso-level) and between intraorganizational resources and capabilities (micro-level) - which all rely on the interdependencies and reciprocal feedbacks (e.g. Dobson \& Breslin, 2013).

These assumptions of co-evolutionary scholars (i.e. Breslin, 2011) have been used as a theoretical platform for better explaining the translation of the replicator and interactors concepts from biological to socio-economic studies. The replicator is an element that passes, like genes, to others through successive replications, 
whereas interactors are entities that interact with their environment causing differential replications. However, the difficulty in implementing these two concepts in co-evolution 'relates to the identification of replicators and interactors for each level within an organization's hierarchy' (Breslin, 2016, p. 1022).

Notwithstanding, assumptions of the co-evolutionary approach have been verified by different scholars in explaining, for example, firms' and sectorial performance according to the stage of their life cycle (Uli, 2018), the relationship between anticipatory cognitive frameworks and the multi-level co-evolution of practices within organisations (Breslin, 2016) and the biased cognitive mechanisms of managers in making decisions. Abatecola (2014a) and Abatecola et al. (2018) have demonstrated that the co-evolutionary approach is a suitable lens for clarifying the cognitive mechanisms on the basis of managers' decisions within organisations. In particular, while making decisions, managers affect/are affected by their social and physical environment, according to the thinking in circles and multi-level assumptions, as well as by the imprinting derived by their past decisions (which are on the basis of the enactment process). This approach, in practice, has been demonstrated as helpful in dealing with different processes and units of analysis firms, sectors and management decisions (see the cited works of Breslin for the adoption of the co-evolutionary approach on habits, routines and cognitive frameworks). From that, adoption of the coevolutionary approach in the study of the role of affect in management decisions can be pivotal for a better understanding of the elements of this relationship and their influencing connections, which have been partially demonstrated - through not considering different levels of influence and affect moderations - to rely on circular relationships, interdependence and reciprocal feedbacks (Lerner et al., 2013).

\section{Methodology}

As well reported by Edmondson and McManus (2007, p. 1159), 'when a topic of interest has been studied extensively, researchers can use prior literature to identify critical independent, dependent and control variables and to explain general mechanisms underlying the phenomenon'. Considering the mature stage reached by the literature concerned with the role of affect in management decisions (as pointed out in the introduction and theoretical background of this work), the SLR has been identified, similarly to other scholars (Crossan \& Apaydin, 2010; De Vita, Mari, \& Poggesi, 2013; Mari \& Poggesi, 2013), as the suitable research design to consolidate and synthesise the identified academic research into a comprehensive framework.

According to Tranfield, Denyer, and Smart (2003), this method differs from the traditional narrative reviews by: $i$ ) assisting in linking future research to the questions and concerns that have been posed by past research and ii) being more explicit in the selection process, by employing rigorous and reproducible evaluation methods. The systematic approach to the collection and analysis of the papers is depicted as follows:

1) The databases for the identification of the studies are: a) Business Source Premier (EBSCO); $b$ ) ProQuest's ABI/Informs; $c$ ) ISI Web of Science; $d$ ) Scopus and $e$ ) PsycINFO;

2) Only peer-reviewed journal articles published in English (not considered are: books, book chapters/reviews, practitioner papers, conference proceedings, working papers, reports, unpublished works; see on this point Tranfield et al., 2003) but contributions treating emotions as a psychological trait (i.e. emotional stability and emotional intelligence; see Delgado Garcia et al., 2015) have been considered to enhance the quality control;
3) The substantive relevance of contributions to the theme has been ensured by requiring that the selected abstracts contained at least one of the following words: 'affect*', 'feel", 'emotion*', 'mood", 'state*' and 'temperament*' (these keywords have been derived following Delgado Garcia et al., 2015). 443,990 results were produced.

4) The substantive relevance of contributions to the theme has been ensured by requiring that the selected abstracts contained at least one of the following words: 'decision*', 'choic*', 'preference*' and 'judg*' (used synonymously by Kahneman, 2011). 48,985 results were produced.

5) Only articles regarding organisations' issues have been considered, by using the keyword 'organization"' and its synonyms: 'compan*', 'manag*', 'corporat*', 'firm*', 'business*', 'enterprise*', 'venture*' and 'start-up"' (these keywords have been derived following De Vita et al., 2013). 5629 results were produced.

6) The resulting articles were scanned by reading all the abstracts to ensure their substantive context, mainly according to their coherence with the 'research question' and 'investigated variables' regarding the aim of the review. 725 results were produced.

7) The remaining papers were read through to ensure their alignment with the research objective according to two quality assessment criteria: theoretical and methodology/data robustness. In particular, as done by Poggesi et al. (2015), the following scores have been assigned to the resulting papers: 1) poor awareness of the relevant literature and poor research design; 2) basic awareness of the relevant literature and/or the research design could be improved; and 3) deep and broad knowledge of the existing literature and/or a sophisticated research design. Then, the sum of the scores of the theoretical robustness and methodology robustness has been done. Articles scoring below or equal to 3 have been excluded from the sample. 297 results were produced.

8) Duplicates from the databases have been eliminated and 13 contributions added following the snowballing technique. A final sample of 123 papers emerged.

9) The thematic analysis followed the mixed inductive-deductive method by Braun and Clarke (2006). In particular, contributions have been coded, in primis, according to the already outlined four mechanisms of affect in decision making (Lerner et al., 2013) and, in secundis, to the different mechanisms that emerged after reading the selected articles.

\section{Findings}

\subsection{Descriptive statistics}

Articles on the role of affect in management decisions started appearing in 1982 (Bell, 1982). However, 90\% of the contributions have been published in the last 15 years, highlighting the increasing importance of this research line. Among the 123 articles, empirical works are in the majority $(\mathrm{N}=85 ; 70 \%)$; then there are qualitative case studies $(\mathrm{N}=25 ; 20 \%)$, conceptual articles $(\mathrm{N}=9 ; 7 \%)$ and general reviews/meta-analyses $(\mathrm{N}=4 ; 3 \%)$, demonstrating that it is a growing field and past its nascent period. Affective states are generally investigated through the Positive and Negative Affect Schedule (PANAS) $(\mathrm{N}=53 ; 59 \%)$ and then commonly investigated by analysis of variance $(\mathrm{N}=60 ; 75 \%)$. The majority of articles in the scope investigate the role of emotions (stricto sensu) in management decisions $(\mathrm{N}=65 ; 53 \%)$, whereas the remaining are focused on $\operatorname{mood}(\mathrm{N}=33 ; 27 \%)$ and temperament $(\mathrm{N}=14 ; 11 \%) ; 11$ articles (9\%) refer to affect in general.

Contributions (in Table 1 is reported a sample) have been 
Table 1

A sample of the collected and analysed articles.

\begin{tabular}{|c|c|c|c|c|c|c|c|c|c|}
\hline \multicolumn{2}{|c|}{ Author(s) } & \multirow{2}{*}{$\begin{array}{l}\text { Year } \\
2011\end{array}$} & \multirow{2}{*}{$\begin{array}{l}\text { Type of } \\
\text { article } \\
\text { Empirical } \\
\text { paper }\end{array}$} & \multirow{2}{*}{$\begin{array}{l}\text { Setting } \\
\begin{array}{l}\text { One Chinese } \\
\text { university }\end{array}\end{array}$} & \multirow{2}{*}{$\begin{array}{l}\begin{array}{l}\text { Data } \\
\text { collection } \\
\text { method }\end{array} \\
\begin{array}{l}\text { Laboratory } \\
\text { experiment }\end{array}\end{array}$} & \multirow{2}{*}{$\begin{array}{l}\text { Affective state(s) } \\
\text { Irritation, anger, } \\
\text { contempt, envy, } \\
\text { jealousy, sadness, } \\
\text { joy, happiness, } \\
\text { shame, fear and } \\
\text { surprise }\end{array}$} & \multirow{2}{*}{$\begin{array}{l}\text { Data analysis } \\
\text { method } \\
\begin{array}{l}\text { Hierarchical } \\
\text { regressions }\end{array}\end{array}$} & \multirow{2}{*}{$\begin{array}{l}\text { Main findings } \\
\text { Participants that showed less } \\
\text { fear of failure, less regret and } \\
\text { anger of failure evaluated a } \\
\text { new venture as an } \\
\text { opportunity }\end{array}$} & \multirow{2}{*}{$\begin{array}{l}\text { Cluster } \\
\text { Affective states } \\
\text { shape decisions } \\
\text { by the content of } \\
\text { thought }\end{array}$} \\
\hline 1 & Li, Y. & & & & & & & & \\
\hline 2 & Guzak, J.R. & 2015 & $\begin{array}{l}\text { Empirical } \\
\text { paper }\end{array}$ & $\begin{array}{l}\text { A College of } \\
\text { Business } \\
\text { Administration } \\
\text { at a large } \\
\text { southwestern } \\
\text { University }\end{array}$ & $\begin{array}{l}\text { Laboratory } \\
\text { experiment }\end{array}$ & $\begin{array}{l}\text { Positive and } \\
\text { negative } \\
\text { emotions of the } \\
\text { PANAS scale }\end{array}$ & $\begin{array}{l}\text { Analysis of } \\
\text { Variance }\end{array}$ & $\begin{array}{l}\text { Participants experiencing a } \\
\text { positive or neutral affective } \\
\text { state made more utilitarian } \\
\text { decisions regarding an ethical } \\
\text { dilemma than those in the } \\
\text { negative affective state }\end{array}$ & $\begin{array}{l}\text { Affective states } \\
\text { shape decisions } \\
\text { by the content of } \\
\text { thought }\end{array}$ \\
\hline 3 & $\begin{array}{l}\text { Kollmann, T., } \\
\text { Stöckmann, C., \& } \\
\text { Kensbock, J. M. }\end{array}$ & 2017 & $\begin{array}{l}\text { Empirical } \\
\text { paper }\end{array}$ & $\begin{array}{l}\text { One German } \\
\text { university and } \\
\text { two on-line } \\
\text { panels }\end{array}$ & $\begin{array}{l}\text { Laboratory } \\
\text { experiment }\end{array}$ & Fear of failure & $\begin{array}{l}\text { Structural } \\
\text { equation } \\
\text { modelling }\end{array}$ & $\begin{array}{l}\text { Participants experiencing fear } \\
\text { of failure negatively } \\
\text { evaluated a business } \\
\text { opportunity }\end{array}$ & $\begin{array}{l}\text { Affective states } \\
\text { shape decisions } \\
\text { by the content of } \\
\text { thought }\end{array}$ \\
\hline 4 & $\begin{array}{l}\text { Au, K., Chan, F., } \\
\text { Wang, D., \& } \\
\text { Vertinsky, I. }\end{array}$ & 2003 & $\begin{array}{l}\text { Empirical } \\
\text { paper }\end{array}$ & $\begin{array}{l}\text { One Chinese } \\
\text { university }\end{array}$ & $\begin{array}{l}\text { Laboratory } \\
\text { experiment }\end{array}$ & $\begin{array}{l}\text { Pleasant, neutral } \\
\text { and unpleasant } \\
\text { moods }\end{array}$ & $\begin{array}{l}\text { Analysis of } \\
\text { Variance, } \\
\text { planned } \\
\text { comparisons } \\
\text { and Pearson's } \\
\text { correlations }\end{array}$ & $\begin{array}{l}\text { Participants that made } \\
\text { financial decisions in a good } \\
\text { mood had a less accurate } \\
\text { decision-making process than } \\
\text { those in neutral or bad moods }\end{array}$ & $\begin{array}{l}\text { Affective states } \\
\text { shape the depth } \\
\text { of thought }\end{array}$ \\
\hline 5 & $\begin{array}{l}\text { Blay, A.D., Kadous, } \\
\text { K., \& Sawers, K. }\end{array}$ & 2012 & $\begin{array}{l}\text { Empirical } \\
\text { paper }\end{array}$ & $\begin{array}{l}\text { One undefined } \\
\text { university }\end{array}$ & $\begin{array}{l}\text { Laboratory } \\
\text { experiment }\end{array}$ & $\begin{array}{l}\text { Excitement, } \\
\text { nervousness, } \\
\text { enthusiasm, } \\
\text { anxiety, } \\
\text { inspiration, } \\
\text { worry, } \\
\text { determination } \\
\text { and sadness }\end{array}$ & $\begin{array}{l}\text { Analysis of } \\
\text { Variance }\end{array}$ & $\begin{array}{l}\text { Participants experiencing } \\
\text { negative affective states were } \\
\text { more efficient in their search } \\
\text { strategy of cues than those } \\
\text { who experienced positive } \\
\text { affective states }\end{array}$ & $\begin{array}{l}\text { Affective states } \\
\text { shape the depth } \\
\text { of thought }\end{array}$ \\
\hline 6 & $\begin{array}{l}\text { Winterich, K. P., } \\
\text { Morales, A. C. \& } \\
\text { Mittal, V. }\end{array}$ & 2015 & $\begin{array}{l}\text { Empirical } \\
\text { paper }\end{array}$ & $\begin{array}{l}\text { One south- } \\
\text { western } \\
\text { university in } \\
\text { the U.S. and one } \\
\text { on-line panel }\end{array}$ & $\begin{array}{l}\text { Laboratory } \\
\text { experiment }\end{array}$ & $\begin{array}{l}\text { Disgust, } \\
\text { happiness and } \\
\text { sadness }\end{array}$ & $\begin{array}{l}\text { Analysis of } \\
\text { Variance and } \\
\text { Multivariate } \\
\text { Analysis of } \\
\text { Variance }\end{array}$ & $\begin{array}{l}\text { Participants that felt } \\
\text { disgusted or happy relied on a } \\
\text { heuristic-based processing, } \\
\text { leading to a stronger reliance } \\
\text { on the magnitude of } \\
\text { consequences when forming } \\
\text { ethical judgements. } \\
\text { Participants that felt sadness } \\
\text { relied on a more systematic } \\
\text { processing, resulting in a } \\
\text { weaker reliance on the } \\
\text { magnitude of consequences }\end{array}$ & $\begin{array}{l}\text { Affective states } \\
\text { shape the depth } \\
\text { of thought }\end{array}$ \\
\hline 7 & $\begin{array}{l}\text { Zeelenberg, M., van } \\
\text { Dijk, W. W., van der } \\
\text { Pligt, J., Manstead, } \\
\text { A.S.R., van Empelen, } \\
\text { P. \& Reinderman, D. }\end{array}$ & 1998 & $\begin{array}{l}\text { Empirical } \\
\text { paper }\end{array}$ & $\begin{array}{l}\text { University of } \\
\text { Amsterdam }\end{array}$ & $\begin{array}{l}\text { Laboratory } \\
\text { experiment }\end{array}$ & Regret & $\begin{array}{l}\text { Analysis of } \\
\text { Variance and } \\
\text { Multivariate } \\
\text { Analysis of } \\
\text { Variance }\end{array}$ & $\begin{array}{l}\text { Participants experiencing } \\
\text { regret decided to act in order } \\
\text { to change the course of the } \\
\text { occurred event }\end{array}$ & $\begin{array}{l}\text { Affective states } \\
\text { shape decisions } \\
\text { by goal activation }\end{array}$ \\
\hline 8 & Fredin, A.J. & 2011 & $\begin{array}{l}\text { Empirical } \\
\text { paper }\end{array}$ & $\begin{array}{l}\text { A large } \\
\text { midwestern } \\
\text { university }\end{array}$ & $\begin{array}{l}\text { Laboratory } \\
\text { experiment }\end{array}$ & Regret & $\begin{array}{l}\text { Analysis of } \\
\text { Variance }\end{array}$ & $\begin{array}{l}\text { Participants anticipating the } \\
\text { regret of blowing the whistle } \\
\text { decided to stay silent about } \\
\text { the unethical situation they } \\
\text { knew about }\end{array}$ & $\begin{array}{l}\text { Affective states } \\
\text { shape decisions } \\
\text { by goal activation }\end{array}$ \\
\hline 9 & $\begin{array}{l}\text { Klaukien, A., } \\
\text { Shepherd, D.A., \& } \\
\text { Patzelt, H. }\end{array}$ & 2013 & $\begin{array}{l}\text { Empirical } \\
\text { paper }\end{array}$ & $\begin{array}{l}\text { Owner } \\
\text { - managers of } \\
\text { young firms }\end{array}$ & $\begin{array}{l}\text { Field } \\
\text { experiment }\end{array}$ & Excitement & $\begin{array}{l}\text { Hierarchical } \\
\text { Linear } \\
\text { Modelling }\end{array}$ & $\begin{array}{l}\text { Owner-managers of young } \\
\text { firms experiencing } \\
\text { excitement were more prone } \\
\text { to exploit business } \\
\text { opportunities }\end{array}$ & $\begin{array}{l}\text { Affective states } \\
\text { shape decisions } \\
\text { by goal activation }\end{array}$ \\
\hline 10 & $\begin{array}{l}\text { Visser, V.A., } \\
\text { Knippenberg D., } \\
\text { Kleef, G.A., \& Wisse, } \\
\text { B. }\end{array}$ & 2013 & $\begin{array}{l}\text { Empirical } \\
\text { paper }\end{array}$ & $\begin{array}{l}\text { A business } \\
\text { school in The } \\
\text { Netherlands }\end{array}$ & $\begin{array}{l}\text { Laboratory } \\
\text { experiment }\end{array}$ & $\begin{array}{l}\text { Happiness and } \\
\text { sadness }\end{array}$ & $\begin{array}{l}\text { Analysis of } \\
\text { Variance }\end{array}$ & $\begin{array}{l}\text { Leaders that display } \\
\text { happiness enhance followers' } \\
\text { creative performance. In } \\
\text { contrast, leaders who display } \\
\text { sadness enhance followers' } \\
\text { analytical performance }\end{array}$ & $\begin{array}{l}\text { Affective states } \\
\text { influence } \\
\text { interpersonal } \\
\text { decision making }\end{array}$ \\
\hline 11 & $\begin{array}{l}\text { Yang, M.-Y., Cheng, } \\
\text { F.-C. \& Chuang, A. }\end{array}$ & 2015 & $\begin{array}{l}\text { Empirical } \\
\text { paper }\end{array}$ & $\begin{array}{l}\text { An undefined } \\
\text { university }\end{array}$ & $\begin{array}{l}\text { Laboratory } \\
\text { experiment }\end{array}$ & $\begin{array}{l}\text { Positive and } \\
\text { negative } \\
\text { emotions of the } \\
\text { PANAS scale }\end{array}$ & $\begin{array}{l}\text { Ordinary } \\
\text { least squares } \\
\text { regressions } \\
\text { and } \\
\text { Hierarchical } \\
\text { Linear } \\
\text { Modelling }\end{array}$ & $\begin{array}{l}\text { Participants that show high } \\
\text { levels of positive trait affect } \\
\text { encourage their counterparts } \\
\text { to search for conflict } \\
\text { resolution strategies }\end{array}$ & $\begin{array}{l}\text { Affective states } \\
\text { influence } \\
\text { interpersonal } \\
\text { decision making }\end{array}$ \\
\hline 12 & $\begin{array}{l}\text { Davis, B.C., } \\
\text { Hmieleski, K.M., }\end{array}$ & 2017 & $\begin{array}{l}\text { Empirical } \\
\text { paper }\end{array}$ & & $\begin{array}{l}\text { Laboratory } \\
\text { experiment }\end{array}$ & $\begin{array}{l}\text { Positive and } \\
\text { negative }\end{array}$ & & $\begin{array}{l}\text { Founders that exhibit passion } \\
\text { during their pitch positively }\end{array}$ & $\begin{array}{l}\text { Affective states } \\
\text { influence }\end{array}$ \\
\hline
\end{tabular}


Table 1 (continued)

\begin{tabular}{|c|c|c|c|c|c|c|c|c|c|}
\hline \multicolumn{2}{|c|}{ Author(s) } & \multirow[t]{2}{*}{ Year } & \multirow{2}{*}{$\begin{array}{l}\text { Type of } \\
\text { article }\end{array}$} & \multirow{2}{*}{$\begin{array}{l}\text { Setting } \\
\text { Two } \\
\text { universities in } \\
\text { the U.S. }\end{array}$} & \multirow{2}{*}{$\begin{array}{l}\text { Data } \\
\text { collection } \\
\text { method }\end{array}$} & \multirow{2}{*}{$\begin{array}{l}\text { Affective state(s) } \\
\text { emotions of the } \\
\text { PANAS scale }\end{array}$} & \multirow{2}{*}{$\begin{array}{l}\text { Data analysis } \\
\text { method } \\
\text { Hierarchical } \\
\text { Linear } \\
\text { Modelling }\end{array}$} & \multirow{2}{*}{$\begin{array}{l}\text { Main findings } \\
\text { affect the venture's strategic } \\
\text { decision to invest in the } \\
\text { company }\end{array}$} & \multirow{2}{*}{$\begin{array}{l}\text { Cluster } \\
\text { interpersonal } \\
\text { decision making }\end{array}$} \\
\hline & $\begin{array}{l}\text { Webb, J.W., \& } \\
\text { Coombs, J.E. }\end{array}$ & & & & & & & & \\
\hline 13 & $\begin{array}{l}\text { Desivilya, S.H. \& } \\
\text { Yagil, D.D. }\end{array}$ & 2005 & $\begin{array}{l}\text { Empirical } \\
\text { paper }\end{array}$ & $\begin{array}{l}\text { Medical teams } \\
\text { of health } \\
\text { organisations } \\
\text { in northern } \\
\text { Israel }\end{array}$ & $\begin{array}{l}\text { Field } \\
\text { experiment }\end{array}$ & $\begin{array}{l}\text { Positive and } \\
\text { negative } \\
\text { emotions of the } \\
\text { PANAS scale }\end{array}$ & $\begin{array}{l}\text { Linear } \\
\text { regressions }\end{array}$ & $\begin{array}{l}\text { Positive emotions among } \\
\text { team members push to a } \\
\text { cooperative approach in } \\
\text { solving conflicts, whereas } \\
\text { negative emotions carry team } \\
\text { members to adopt a } \\
\text { contentious pattern in solving } \\
\text { conflicts }\end{array}$ & $\begin{array}{l}\text { Affective } \\
\text { contagion } \\
\text { influences } \\
\text { decision-making } \\
\text { group dynamics }\end{array}$ \\
\hline 14 & $\begin{array}{l}\text { Tee, E.Y.J., } \\
\text { Ashkanasy, N.M., \& } \\
\text { Paulsen, N. }\end{array}$ & 2013 & $\begin{array}{l}\text { Empirical } \\
\text { paper }\end{array}$ & $\begin{array}{l}\text { An Australian } \\
\text { university }\end{array}$ & $\begin{array}{l}\text { Laboratory } \\
\text { experiment }\end{array}$ & $\begin{array}{l}\text { Positive and } \\
\text { negative } \\
\text { emotions of the } \\
\text { PANAS scale }\end{array}$ & $\begin{array}{l}\text { Analysis of } \\
\text { Variance and } \\
\text { linear } \\
\text { regressions }\end{array}$ & $\begin{array}{l}\text { Leaders high on neuroticism } \\
\text { performed less effectively } \\
\text { than leaders low on } \\
\text { neuroticism when interacting } \\
\text { with negative-mood } \\
\text { followers }\end{array}$ & $\begin{array}{l}\text { Affective } \\
\text { contagion } \\
\text { influences } \\
\text { decision-making } \\
\text { group dynamics }\end{array}$ \\
\hline 15 & $\begin{array}{l}\text { Johnson, G. \& } \\
\text { Connelly, S. }\end{array}$ & 2014 & $\begin{array}{l}\text { Empirical } \\
\text { paper }\end{array}$ & $\begin{array}{l}\text { A southwestern } \\
\text { university in } \\
\text { the U.S. }\end{array}$ & $\begin{array}{l}\text { Laboratory } \\
\text { experiment }\end{array}$ & $\begin{array}{l}\text { Anger and } \\
\text { disappointment }\end{array}$ & $\begin{array}{l}\text { Analysis of } \\
\text { Covariance }\end{array}$ & $\begin{array}{l}\text { Participants experiencing } \\
\text { guilt in response to } \\
\text { disappointed displays } \\
\text { resulted in beneficial } \\
\text { behaviours and attitudes, } \\
\text { whereas participants } \\
\text { experiencing anger in } \\
\text { response to angry displays } \\
\text { were found to be socially } \\
\text { detrimental }\end{array}$ & $\begin{array}{l}\text { Affective } \\
\text { contagion } \\
\text { influences } \\
\text { decision-making } \\
\text { group dynamics }\end{array}$ \\
\hline 16 & $\begin{array}{l}\text { Maitlis, S., \& } \\
\text { Ozcelik, H. }\end{array}$ & 2004 & $\begin{array}{l}\text { Theoretical } \\
\text { paper }\end{array}$ & - & - & $\begin{array}{l}\text { Anxiety, fear, } \\
\text { shame, anger and } \\
\text { embarrassment }\end{array}$ & - & $\begin{array}{l}\text { The recurring spread of } \\
\text { negative emotions through } \\
\text { processes of empathetic } \\
\text { transmission and emotional } \\
\text { contagion at different } \\
\text { interacting levels can create a } \\
\text { toxic organizational } \\
\text { environment for } \\
\text { management decisions. In } \\
\text { contrast, expressing a lack of } \\
\text { feeling and use of } \\
\text { rationalization can prevent } \\
\text { this vicious circle }\end{array}$ & $\begin{array}{l}\text { Multi-level } \\
\text { adapted affective } \\
\text { states reduce } \\
\text { biased decision } \\
\text { making }\end{array}$ \\
\hline 17 & $\begin{array}{l}\text { Kligyte, V., } \\
\text { Connelly, S., Thiel, } \\
\text { C. \& Devenport, L. }\end{array}$ & 2013 & $\begin{array}{l}\text { Empirical } \\
\text { paper }\end{array}$ & $\begin{array}{l}\text { A midwestern } \\
\text { university in } \\
\text { the U.S. }\end{array}$ & $\begin{array}{l}\text { Laboratory } \\
\text { experiment }\end{array}$ & Anger and fear & $\begin{array}{l}\text { Correlations } \\
\text { and } \\
\text { Multivariate } \\
\text { Analysis of } \\
\text { Variance }\end{array}$ & $\begin{array}{l}\text { Participants experiencing } \\
\text { anger inhibited ethical } \\
\text { decision making and } \\
\text { sensemaking. Participants } \\
\text { experiencing fear facilitated } \\
\text { ethical decisions compared to } \\
\text { anger and no emotion } \\
\text { conditions. Emotion } \\
\text { regulation had a significant } \\
\text { decreasing effect on the } \\
\text { negative influences of anger } \\
\text { on sensemaking and ethical } \\
\text { decisions }\end{array}$ & $\begin{array}{l}\text { Multi-level } \\
\text { adapted affective } \\
\text { states reduce } \\
\text { biased decision } \\
\text { making }\end{array}$ \\
\hline 18 & $\begin{array}{l}\text { Wolf, E.B., Lee, J.J., } \\
\text { Sah, S. \& Brooks, } \\
\text { A.W. }\end{array}$ & 2016 & $\begin{array}{l}\text { Empirical } \\
\text { paper }\end{array}$ & $\begin{array}{l}\text { Two panels } \\
\text { (one recruited } \\
\text { on-line) and } \\
\text { students in the } \\
\text { Boston area }\end{array}$ & $\begin{array}{l}\text { Laboratory } \\
\text { experiment } \\
\text { and field } \\
\text { experiment }\end{array}$ & $\begin{array}{l}\text { Distress and } \\
\text { passion }\end{array}$ & $\begin{array}{l}\text { Analysis of } \\
\text { Variance and } \\
\text { mediation } \\
\text { analysis }\end{array}$ & $\begin{array}{l}\text { Participants that reframed } \\
\text { their distress by publicly } \\
\text { attributing it to passion } \\
\text { influenced the perceptions of, } \\
\text { and decisions about, the } \\
\text { person who expressed } \\
\text { emotion. Participants } \\
\text { interpreted people who } \\
\text { reframed distress as } \\
\text { competent. Reframing of } \\
\text { emotions also influenced } \\
\text { interpersonal decision- } \\
\text { making; indeed, participants } \\
\text { that reframed their distress as } \\
\text { passion were the chosen } \\
\text { candidate, by responsible of } \\
\text { personnel selections, for a job } \\
\text { position }\end{array}$ & $\begin{array}{l}\text { Multi-level } \\
\text { adapted affective } \\
\text { states reduce } \\
\text { biased decision } \\
\text { making }\end{array}$ \\
\hline
\end{tabular}


thematically analysed. The results of this step are six clusters, the first four are representative of the functions already identified by Lerner et al. (2013), whereas the last two represent the mechanisms that have recently emerged: $i$ ) affective states shape decisions by the content of thought ( $\mathrm{N}=32 ; 26 \%)$, ii) affective states shape the depth of thought $(\mathrm{N}=30 ; 24 \%)$, iii) affect shapes decision making by goal activation $(\mathrm{N}=23 ; 19 \%), i v)$ affect influences interpersonal decision making ( $\mathrm{N}=16 ; 13 \%), v$ ) affective contagion influences decision making group dynamics $(\mathrm{N}=12 ; 10 \%)$ and $v i)$ multi-level adapted affective states reduce biased decision making $(\mathrm{N}=10$; $8 \%$ ). The latter are entirely new research paths; indeed, six papers out of 12 (50\%) within the fifth cluster, and six papers out of ten within the sixth (60\%) have been published in the last 5 years.

\subsection{Affective states shape decisions by the content of thought}

The first scientific contribution that tried to inform about the role of affect in decision making is by Bell (1982). In particular, he demonstrated that the inconsistent behaviour of people in some choice situations is caused by the sense of regret that individuals may experience in facing a setting in which they progressively learn that other alternatives would have been preferable (because of their better outcomes); thus, he showed proves on the failure of the expected utility theory for which decision-making behaviour can be explained by considering money rewards as the only descriptor. Moreover, this first study also assumed that feeling regretful is connected with the sense of responsibility that people have on the choice situation; thus, the more the individual can autonomously make a decision, the greater the perceived likelihood of a possible bad outcome for the chosen alternative.

Despite this first important contribution, later scholars affirmed that what really influences the choice evaluation is the individual's knowledge about the realistic and potential situations' characteristics. In particular, Connolly, Ordonez, and Coughlan (1997) demonstrated that the economic assessment of post-choice alternatives is a matter of reference points (i.e. alternatives' framing) that consequently elicit some emotions to emerge and play an influencing role. Moreover, those who anticipate regret in failing to choose the best alternative can behave in a risk-averse manner, avoiding making decisions for which they may be responsible (Zeelenberg, 1998). In practice, according to these developments, the sense of regret in post-evaluation choices does not depend on the span of control that people have over the situation, but the final decision comes from a process in which anticipated emotions and contextual factors interact (see Lipshitz \& Shulimovitz, 2007).

However, other scholars did not control for the framing of alternatives as causes of affective states; they have increasingly focused on investigating the direct relationship between affective states and the evaluation of business opportunities. Both Finucane, Alhakami, Slovic and Jhonson (2000) and Foo (2009), while studying the relationship between individuals' scores on risk perception and business opportunity evaluation, discovered that people with high values with a fear temperament are usually riskaverse, while those with a happy temperament tend to make more risky choices. This result was confirmed by Li (2011) and some review works (e.g. Delgado Garcia et al., 2015), which generally identified that executives with less anger and regret temperaments tend to make positive evaluations about new business opportunities and also their greater likelihood of success.

\subsection{Affective states shape the depth of thought}

Research on the role of affect in decision making has been concerned, from its inception, with deepening the first insight of Simon (1983) for whom emotions influence managers' information processing (i.e. depth of thought). In contrast with the shared assumption that happy decision makers are inclined towards the use of heuristics rather than systematic decision making, Staw and Barsade (1993) proved that people experiencing positive affect (e.g. being enthusiastic) tend to collect more information. However, other renowned works found different results for this relationship. For example, Elsbach and Barr (1999) found that individuals experiencing a moderately negative mood are significantly more likely than those in a moderately positive mood, to accurately follow all the steps of a structured decision protocol in its correct order. In other words, people with moderate to high levels of positive affect are more inclined to deviate from the beaten path. Yet, Welpe, Sporrle, Grichnik, Michl, and Audretsch (2012), in their research about the effect of emotions on exploitation vs. exploration processes, found a very different result. Indeed, according to their findings, people who feel joy and anger (either a positive or negative affect state) tend towards the exploitation of alternatives (collecting decision-related information) instead of pursuing exploration activities. In contrast, Bachkirov (2015) found that happiness and anger cause the decision maker to process less decision-relevant information.

Findings on the role of regret aversion and moderate fear seem to follow the contrasting results found for the positive affective states. Indeed, Welpe et al. (2012) and Bachkirov (2015) found that fear reduces the executive tendency to exploit established choice alternatives in favour of the exploration of new ones, in contrast with Reb's (2008) and Coget, Haag, and Gibson's (2011) results, which supported the hypothesis that fear and regret aversion are associated with information-related processing. Results seem to be more solid if shifting the focus from emotions to mood. Indeed, according to a meta-analysis on the role of mood in creativity tasks (Davis, 2009), a positive mood significantly enhances creativity. In particular, a positive mood favourably affects creativity in pure ideating tasks, while a negative mood can result in better performance when applying creativity to problem solving tasks, i.e. that call for a solution, not spreading alternatives. Clearly, the effect of mood on creativity varies according to the type of creative task.

\subsection{Affective states shape decisions by goal activation}

Developments during the '80s and '90s on the role of affect in influencing the content and depth of thought in management decisions, raised the question if affect itself can also be the activator of decision-making processes. In this regard, Hoelzl and Loewenstein (2005) verified that decision makers experiencing anticipated regret for an investment (because of the possibility of being taken over by another investor) were found to be more likely to stick with it rather than leave. This finding was later confirmed by Montes, Rodriguez, and Serrano (2012), who found that executives who have to choose their management style to deal with organizational conflicts tend to use cooperative strategies if they are in a positive mood, otherwise they tend to dominate or avoid conflict strategies. Yet, Delgado-Garcia in his research programme demonstrated that managers who have a negative temperament are related to less risky firm strategies, whereas managers with a positive temperament are more risk-oriented and therefore deviate from conformist strategies (Delgado-Garcia et al., 2010; 2015).

In sum, managers who experience a positive affective state seem to be more proactive to take action and to challenge their position, whereas those in a negative affective state would prefer the status quo. However, some recent works have found contrasting effects. Indeed, according to Hatak and Snellman's (2016) study, anticipated regret, in particular, and negative emotions, generally, can have a proactive effect. In particular, their findings show that positive emotions reduce the search-oriented strategies of executives 
- mainly because they negatively affect executives' motivation to divergently think - whereas, in contrast, negative emotions seem to activate a sense of struggle for survival and consequently push towards the search for new business opportunities. Morever, also regarding the goal activation process, the influence of affect should be read according to the context. As demonstrated by Zhang, Chiu, and Wei (2009), executives who have to decide on blowing the whistle or remaining silent regarding others' unethical behaviours are more prone to report them if, apart from being in a positive mood that causes them to undermine the actions' effects, they perceive an ethical organizational culture.

\subsection{Affective states influence interpersonal decision making}

Stemming from the fact that organisations are based on cooperation among individuals, it is important to understand how the affect of certain individuals towards others influences the decision making of the latter. Scholars have been progressively focused on understanding the effect of leaders' affective states on subordinates (and vice versa) and from peer to peer as well. One of the studies in this direction is by Casciaro and Lobo (2008), who investigated the role of interpersonal affect in task-related network organisations and found that liking or disliking someone on a personal level has a greater impact in making a decision on how to compose a team than the evaluation of task-related competences. In practice, potential partners that elicit a negative affect are assessed as less competent at tasks than those who elicit a positive affect. Moreover, displaying positive emotions also seems favourable in improving others' decision-making processes; as found by Visser, Knippenberg, Kleef, and Wisse (2013), leaders who display happiness or a self-enhancing humour enhance subordinates' creative performance, whereas if they display sadness, then followers would tend to use more analytical approaches.

However, displaying a positive mood can also be detrimental for interpersonal decision making. Indeed, people appearing as happy have been found to be perceived as more naïve than moderately happy decision makers, mainly because they seem not to pay attention to negative information and/or have a biased judgement (Barasch, Levine, \& Schweitzer, 2016). This causes the spread of opportunistic behaviour by counterparts, such as giving biased, self-serving advice.

The display of emotions and/or moods also has an effect on the evaluation phase of the decision-making process. Indeed, Bhattacharjee, Charjee, and Moreno (2017) found that executives' estimations in transfer pricing decisions are more conciliatory when the opponent shows positive emotions than when displaying negative emotions, but this relationship can be the opposite in the absence of a collaborative organizational context. A similar result has also been found by Davis, Hmieleski, Webb, and Coombs (2017), in whose research the opponents' display of passion and creativity while describing business ideas has been discovered carrying to the counterpart positive evaluations of the opportunities presented.

\subsection{Affective contagion influences decision-making group dynamics}

Beside the studies interested in the influence on interpersonal decision making, a number of scholars have focused their attention on the affect escalation from individuals to groups, mainly through the unconscious mimicry of body gestures and speech patterns, or through conscious affective comparisons (i.e. empathic mechanisms); this phenomenon is the affective (or emotional) contagion and has mainly been investigated in teamwork and board dynamics (e.g. Ayoko, Konran, \& Boyle, 2012).

The seminal, specific contribution to affective contagion and its effects on management decisions, is the model drawn by Kelly and Barsade (2001). In particular, the model depicts that individuals entering a group usually bring with them their affective personalities and affective experiences, which later consciously or unconsciously influence the affective composition of the group when individual affective experiences are shared. However, this contagion process, as well as the individual and group affect composition, can be altered by the affective context (e.g. local group norms) in which they are embedded.

Barsade (2002) later tested part of this model and, in particular, whether the direction of the affective contagion (i.e. positive or negative) brings with it different decision-making group strategies. Evidence shows that, in primis, there is no difference in the power of the effect between positive and negative mood contagion and, in secundis, groups experiencing affective contagion try hard to cooperate and tend towards high decision-making task performance; this result is in line with his prior study (Kelly \& Barsade, 2001) on the homogeneity of affective states within groups. Moreover, this relationship appears stronger in the presence of a growing degree of contagion, especially in board dynamics. In other words, if a group member openly displays his/her affective state, he/she is perceived as rich in energy and consequently perceived as confident and enthusiastic. This brings the contagion of other members, who feel stimulated to include others and to let them act as 'order-giver'; vice versa, low emotional energy does not spread to others, and it leads group members to be excluded and to become 'order-takers' (Brundin \& Nordqvist, 2008).

This result was later confirmed by Liu and Maitlis (2014), who found that the energetic exchange among emotional team members brings with it the generation or integration of strategic ideas. Similarly to Barsade (2002), it was found that in the absence of contagion situations, which in turn brings affective diversity (Kouamé, Oliver, \& Poisson-de-Haro, 2015), members experience difficult conflicts that fail to win full commitment. However, the relationship between strategic decision making and affective contagion has recently appeared as co-evolutionary. Indeed, Håkonsson et al. (2016) not only discovered that group members who share positive emotions are more prone to exploitation of management decisions but also that the successful implementation of strategic decisions causes teams to increase the affective contagion.

\subsection{Multi-level adapted affective states reduce biased decision making}

The interpersonal influences and group contagion mechanisms bring uncontrolled effects to management decisions, causing scholars to be increasingly involved in discovering regulating affective strategies, i.e. the techniques aimed at: $i$ ) helping the recognition of experiencing affective states; and ii) identifying the right reaction in expressing them.

One of the first important contributions to this new theme was by Seo and Barrett (2007), who found, through the analysis of the decision-making performance of 101 stock investors, that decision makers able to report and specify their feelings that occurred during a decision-making process are also usually the best performers (in financial terms). This is also confirmed by another study (Thiel, Connelly, \& Griffith, 2012), whose results say that decision makers instructed by their leaders to re-evaluate affective states (taking an outside point of view) reach greater decisional performance than subordinates who were not directed by leaders to regulate their own affective states. Furthermore, other strategies not only have self-regulating effects, but they can also change the impact of affective states on interpersonal decision making. Indeed, as shown by recent studies (Griffith, Connelly, \& Thiel, 2014; Wolf, 
Lee, Sah, \& Brooks, 2016), people who publicly reframe their negative affective states as positive and desirable ones, or are able to redirect others' thoughts, have more chances to change the relationship with an interlocutor from a non-beneficial to a beneficial one or, at least, to experience fewer conflicts. However, if the use of these tactics is too evident, they can lead to greater negative effects (Williams \& Emich, 2014).

The ability of people to manage their own and others' affective states has been called emotional intelligence and, since the early years of this century, has been considered as a pivotal competence for the effectiveness of leaders' decision-making processes (George, 2000). However, the new advancements within this theme increasingly embracing the co-evolutionary perspective (Abatecola, 2014a; 2014b; Breslin, 2011; 2016) - are better defining the regulating mechanisms, which are now conceived as not only based on the ability of the individual, but also on the (more uncontrollable) adaptation mechanisms occurring within the decision-making context. The first recent steps towards this view have been by Ashkanasy (2015) and Fink and Yolles (2015), who approached the regulating affective states' theme from an interactive multi-level perspective (the main assumption of co-evolutionary scholars; Abatecola, 2014b). According to these new studies, affective states in organisations are regulated by five interacting levels: $i$ ) within a person (affective states are regulated by the individual's neurophysiology); ii) between persons (individual affective states are regulated by personal foci); iii) interpersonal interactions (affective states are regulated by dyads' affective interactions); iv) groups (affective states are regulated by groups' affective composition/interactions); and $v$ ) organization (affective states are regulated by the organizational culture/climate and policies; see, Koskina \& Keithley, 2010; Zhang et al., 2009). In sum, regulating affective states, if wisely managed, can reduce biased decision making.

\section{Discussions}

As a premise, five of the six mechanisms can be summed up in the following two categories: i) affective states' influences connected with the decision-making process itself (i.e. content/depth of thought, and goal activation) and ii) affective states' influences connected with social interaction (i.e. interpersonal decision making/affective contagion). These two mechanisms do not operate in a stand-alone way but are at different levels interconnected: multilevel adaptation of affective states. From these considerations, a proposed model for the role of affect on management decisions is offered in Fig. 1.
From the prior literature, it emerges that incidental influences, such as the effect of contextual factors (Lipshitz \& Shulimovitz, 2007) and/or personality traits, are the main drivers of decision makers' affective states (Lerner et al., 2013) (A), which are here considered as the interacting elements among individuals and groups, or can directly influence cognition at the individual, group and organizational levels $\left(\mathrm{A}^{1}\right)$. In practice, as depicted in Fig. 1, current emotions are responsible for goal activation and are influenced by multi-level factors, including expected outcomes and contextual (group and organizational) environments. Among these, there are, from the previous literature, affective states elicited by the neurophysiology of the individual (Damasio, 1994) and his/her personal features (Haynie et al., 2017), which can also present a goal that, in turn, activates the decision-making activity and/or can affect the conscious and unconscious evaluation of the problem situation (B), in terms of depth (Welpe et al., 2012) and content of thought (Li, 2011). However, the latter analytical process on the basis of the decision-making activity (as already mentioned by Lerner et al., 2013) can cause stress/frustration, which, in turn, modifies the prior affective base $\left(\mathrm{B}^{1}\right)$. During this process, and this has not been detected previously, the individual decision maker may be able to self-regulate (C) its affective state in order to emotionally influence the decision-making process (Wolf et al., 2016). Individuals' affective states that are perceived by others at dyadic, group (D) and organizational level (E) - can also affect their counterparts' analytical process (i.e. interpersonal decision making) as well as others' affective states (i.e. emotional contagion) (Fink \& Yolles, 2015). These two mechanisms, together with selfregulation, work as replicators of the interacting affective states; according to the adoption of a co-evolutionary lens, affective states positioned at different levels affect each other through their contagion and consequently decisions.

Finally, after the analytical activity, the management decision is ready to be taken (F) and decision makers try to forecast its expected results $(G)$. These forecasts, however, determine some anticipatory positive or negative affective states that directly influence the analytical process (Hoelzl \& Loewenstein, 2005) (H) or modify the affective base at all levels (I) (Hatak \& Snellman, 2016). Both the pre- and post-evaluations of the management decision work, in practice, as other replicators of the affective states (apart from the different regulations); within this process, the emotions, moods and temperaments that are selected and transmitted are those that have been felt by the individual, dyad or group when analysing the management decision.

The predominant affective states within an organization are the

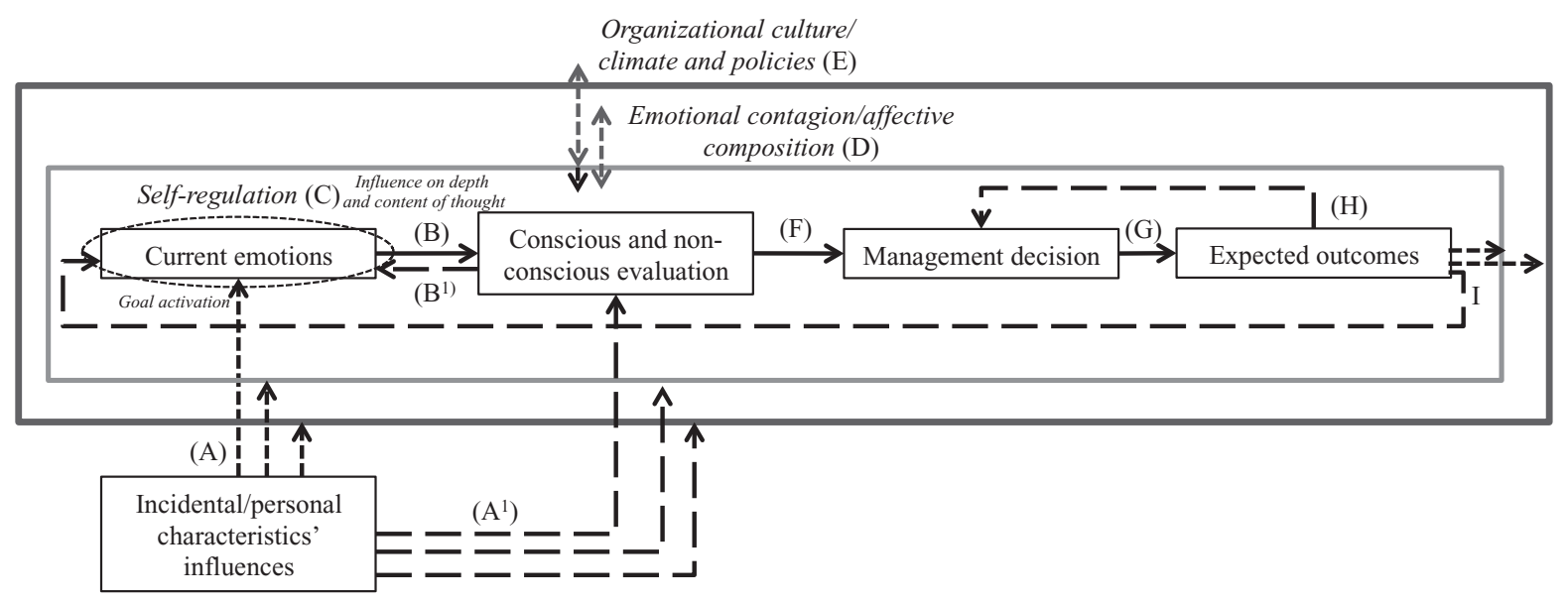

Fig. 1. A proposed co-evolutionary model of affective influences on management decision. 
product of the different replications occurring at each intraorganizational level and/or during the choice evaluation. The preand post-analyses of the management decision reinforce, when consistent with the initial affective states, the emotional base of the organization, creating an emotional lock-in effect according to a path-dependence logic (Abatecola, 2014a); organisations become trapped within their emotional culture by which the same typologies of management decisions are progressively made because of the similar affective base they raise. In other words, the occurrence of a series of successful/dramatic management decisions bring to positive/negative affective states that influence the replication of emotions, moods and temperaments, according to a selfreinforcing virtuous/vicious cycle, till an existing or new individual/group is able to strongly modify the replication of affective states. The entire management decision process can be influenced in whatever moment by the individual/group/organizational factors (already depicted in $A, A^{1}, D$ and $E$ ), bringing to the adaptation of the affective state, i.e. everyone is object and subject of affective influence, influencing other affective states or adapting their own. Therefore, the adoption of a co-evolutionary lens is useful to understand interconnections among the depicted mechanisms and it works as the basis for their theoretical integration. Indeed, according to this perspective, affective states are the product of a circular multi-level feedback, which is a fundamental property of co-evolution (e.g. Lewin \& Volberda, 2005). In particular, the coevolutionary approach finds its roots in the watershed work by Weick (1969) on the sense-making construct and subsequent thinking in circles concept (Abatecola, 2014a; Abatecola et al., 2018). According to Weick (1969), the external world is not objectively existent but is enacted (i.e. sense-making) by people at both an individual and group level. Concurrently, thinking in circles (Benson, 1977) occurs because people's enactment of the external reality retroactively influences their evolving behaviour (Breslin, 2011).

Following this theoretical perspective, the two identified large categories of affective states' mechanisms find their integration on the basis of the multi-level adaptation dynamic, which is another fundamental principle of co-evolution (Abatecola, 2014a; 2014b; Breslin, 2011; 2016). Therefore, affective states' influences generated by the decision-making process itself interact with those determined by the social interaction; these two together can enhance or limit their conditioning power according to the interactions happening at different levels (individual/dyads/group/ organization). These multi-level interactions of affective states, in practice, adapt over space and time (the latter in terms of management decisions' phases) bringing different outcomes; from that, the adoption of the co-evolutionary perspective serves as a base for explaining the several inconsistencies detected among the reported evidence of the mechanisms (thematic clusters) analysed. In particular, an affective state is replicated through the different hierarchical levels and can be presumed, especially in the case of positive emotions emanating from the pre- and post-analysis of the management decision to be made, to become the object of a selfreinforcing effect (Abatecola, 2014a). However, the originally identified affective state can bring inconsistent outcomes if negative interacting elements are introduced by the pre- and postevaluation of the management decision, as well as by a reshaping of the replication mechanisms, e.g. through the change of organizational policies or introduction of new individuals in groups (who modify the affective composition).

In sum, when making management decisions, initial affective states evolve through replications, i.e. emotional regulations and/or choice evaluations, bringing the reinforcement or reshaping of the former. When affective states are reinforced, decision makers are progressively pushed to follow an affect heuristic process (Finucane, Alhakami, Slovic, \& Johnson, 2000) by which the pre- and post-evaluations of management decisions will no longer count, leaving greater space to management decisions driven only by the predominant, affective states of the decision maker. To interrupt this way to make management decisions, new interacting elements should be introduced and/or greater emphasis should be placed on the evaluation of management decisions.

\section{Conclusions}

The proposed framework has filled a gap in the management literature regarding the understanding of the influences of affect in management decisions through the adoption of the coevolutionary approach. A key advantage in using this lens to study the role of affect is that it allows the analysis of multi-level relationships using the same theoretical framework and helps to identify bidirectional causations; however, as already pointed out by co-evolutionary scholars (Abatecola, 2014b; Breslin, 2011; 2016), a common problem in the implementation of these lens lies in the identification of discrete units of analysis at each level, as also done in this work. Notwithstanding, from the discussed framework, two theoretical advancements of this contribution can be clearly pointed out: $i$ ) providing an updated and solid framework that describes all the mechanisms behind the influence of affective states in management decisions and ii) shifting the interpretation of affect in management decisions from a cognitive bias (e.g. Finucane et al., 2000; Kahneman, 2011) to an element that interacts with human bounded rationality, featuring management decisions in organisations. Those two are detailed as follows.

First, the ongoing research about the effect of the manager's affective state on his/her management decisions is increasingly faced through the investigation of multi-level affective dynamics. This is mainly because this approach is already based on the multilevel influence logic behind this investigation as well as embedding the sociobiological assumptions of evolutionary psychology, which tries to explain behavioural changes over time and space. However, scholars interested in the empirical explanation of the derived framework should apply it in a dynamic manner by looking at the influence of affective states over time. An example of the huge explanatory power of this lens, when dynamically applied, can be seen in its use by Cafferata (2018) and Uli (2018) for explaining the firm-environment relationship in contrast to the original static use by Hrebiniak and Joyce (1985). Moreover, because of the connections already made in the Upper Echelons Theory between the personality features of the decision maker and his/her emotions and values - from its first conceptualization (Hambrick \& Mason, 1984) to its latest co-evolutionary interpretation (Abatecola \& Cristofaro, 2018) - scholars can deepen this link through empirical works, which are still scarce. Therefore, new research questions emerging from the proposed framework can be as follows: Do affective states at the individual/group/organizational level vary according to the different organizational phases? Is there a correspondence between affective states and personality traits at the individual and group level? Which one is stronger in influencing management decisions? Why?

Second, despite the current trend appearing to define human rationality as entirely driven by affective states - thus, shifting from bounded rationality to bounded emotionality - the bidirectional interconnections between affective states and the conscious/unconscious mental processes are leading to a new framework of human rationality, in which affect and rational thought interact also with the context - and are the complementary halves for explaining the entirety of management decisions. This work massively reinforces the initial intuition by Cristofaro (2017) on the evolution of the concept of bounded rationality, which now embraces irrational forces initially not deeply exploited by Simon 
(1983). The co-evolutionary framework, according to which the role of affect in management decisions has been interpreted, helps explain how and why decision makers act in an intentionally rational or irrational way alternatively according to the context in which they are embedded. Only through the adoption of the multilevel logic, the thinking in circles' principle, and the replicators and interactors elements, can light be shed on why the same decision maker can, for example, act ethically in a whistle-blowing decision when the consequences are regarding people with whom he is not familiar and act unethically when the consequences are regarding friends or family members. Yet, the interpretation of rational and irrational forces as co-evolving interacting elements helps explain why the same decision maker can decide to reject a failing investment based on the poor financial forecasts and to contemporarily support another equally failing project that, however, elicits some positive emotions in the decision maker. Future research should look more at these interactions, such as the following: in which 'weight' are wrong management decisions, the product of decision-making fallacies and affective states' influences? Are emotionally based decisions always worse, in terms' of occurred outcomes, than apparently rational choices? Are emotionally based decisions worse or better than apparently rational choices within family businesses? Is it the same for big corporations? What are the business situations in which rationality should leave the stage to affective states for management decisions?

From a methodological point of view, despite the defining commitment of some scholars (Ashkanasy et al., 2017; Elfenbein, 2007), researchers continue not to clearly distinguish between concepts such as 'mood' and 'emotions' (Winterich, Morales, \& Mittal, 2015). This is reflected in the use of the same measure (PANAS questionnaire) to collect information about different concepts that can lead to inconsistent results (Zeelenberg, 1998). This prevents the implementation of a meta-analysis on the already produced contributions (Walker, Hernandez, \& Kattan, 2008), which can be an important future study, in order to verify the robustness of the connections between affective states and management decisions' features. In this vein, scholars should ask themselves the following: What data collection methods should be implemented to investigate specific affective states? Qualitative methods based on coding and interpreting narratives, i.e. not implementing standardised questionnaires, can bring clearer evidence with, however, the trade-off of not being useful for future meta-analysis works.

Managers (at all levels) should take into account that management decisions are the product of multi-level affective influences, all of which can be objects of regulation. To do that, managers should first collect data about the affective architecture of their own organisations in terms of organizational climate/policies and groups'/individuals' affective composition, then they should consider setting and/or providing the tools to regulate affective states. Practitioners can then transpose the logic depicted by Thaler and Sunstein (2008) from the economic to the management domain, thus drawing an organizational choices' architecture that 'nudges' (i.e. conditions) how people make management decisions in a certain way without taking away the individual's freedom of choice. For example, managers interested in enhancing group creativity for a management decision should consider planning the latter after having spent time in team building activities, so as to significantly improve a positive mood.

The main limitation of this contribution lies in its data collection and analysis criteria. Despite the strong verification of the used keywords for the data collection, they may have led the researcher to identify the final sample in ways that other keywords may not have. The limitation about data analysis criteria lies in the assessment of papers' quality based on the researcher's knowledge and, as explained by this work, affective states; on this point, Tranfield et al. (2003) highlighted that 'the difficulty in specifying and conducting quality assessments of studies is a major challenge in developing a systematic review methodology for management research' (p. 216). These limitations have been consciously taken into account from the very beginning. It is reasonable to believe that the proper procedure of the conducted systematic review has reduced the probability that not included research would have contained information that would critically alter conclusions.

\section{References}

Abatecola, G. (2014a). Untangling self-reinforcing processes in managerial decision making. Co-evolving heuristics? Management Decision, 52(5), 934-949.

Abatecola, G. (2014b). Research in organizational evolution. What comes next? European Management Journal, 32(3), 434-443.

Abatecola, G., Caputo, A., \& Cristofaro, M. (2018). Reviewing cognitive distortions in managerial decision making. Towards an integrative co-evolutionary framework. The Journal of Management Development, 37(5), 409-424.

Abatecola, G., \& Cristofaro, M. (2018). Hambrick and Mason's "upper echelons theory": Evolution and open avenues. Journal of Management History. https:/ doi.org/10.1108/JMH-02-2018-0016.

Ashkanasy, N. M. (2015). Emotions in organizations: A multi-level perspective. Multi-Level Issues in Organizational Behavior and Strategy, 2, 9-54.

Ashkanasy, N. M., Humphrey, R. H., \& Huy, Q. N. (2017). Integrating emotions and affect in theories of management. Academy of Management Review, 42(2), 175-189.

Au, K., Chan, F., Wang, D., \& Vertinsky, I. (2003). Mood in foreign exchange trading Cognitive processes and performance. Organizational Behavior and Human Decision Processes, 91(2), 322-338.

Ayoko, O. B., Konran, A. M., \& Boyle, M. V. (2012). Online work: Managing conflict and emotions for performance in virtual teams. European Management Journal, 30(2), 156-174.

Bachkirov, A. (2015). Management decision making under specific emotions. Journa of Managerial Psychology, 30(7), 861-874.

Barasch, A., Levine, E. E., \& Schweitzer, M. E. (2016). Bliss is ignorance: How the magnitude of expressed happiness influences perceived naiveté and interpersonal exploitation. Organizational Behavior and Human Decision Processes, 137, 184-206.

Baron, R. A. (2009). The role of affect in the entrepreneurial process. Academy of Management Review, 33(2), 328-340.

Barsade, S. G. (2002). The ripple effect: Emotional contagion and its influence on group behavior. Administrative Science Quarterly, 47(4), 644-675.

Barsade, S. G., \& Gibson, D. E. (2007). Why does affect matter in organizations? Academy of Management Perspectives, 21(1), 36-60.

Barsade, S. G., Ward, A. J., Turner, J. D. F., \& Sonnenfeld, J. A. (2000). To your heart's content: A model of affective diversity in top management teams. Administrative Science Quarterly, 45(4), 802-836.

Bell, D. E. (1982). Regret in decision making under uncertainty. Operations Research 30(5), 961-981.

Benson, J. K. (1977). Organizations: A dialectical view. Administrative Science Quarterly, 22(1), 1-21.

Bhattacharjee, S., Charjee, S. B., \& Moreno, K. K. (2017). The role of informal controls and a bargaining opponents' emotions on transfer pricing judgments. Contemporary Accounting Research, 29(4), 1087-1108.

Blay, A. D., Kadous, K., \& Sawers, K. (2012). The impact of risk and affect on information search efficiency. Organizational Behavior and Human Decision Processes, 117(1), 80-87.

Braun, V., \& Clarke, V. (2006). Using thematic analysis in psychology. Qualitative Research in Psychology, 3(2), 77-101.

Breslin, D. (2011). Interpreting futures through the multi-level co-evolution of organizational practices. Futures, 43(9), 1020-1028.

Breslin, D. (2016). What evolves in organizational co-evolution? Journal of Man agement \& Governance, 20(1), 45-67.

Brundin, E., \& Nordqvist, M. (2008). Beyond facts and figures: The role of emotions in boardroom dynamics. Corporate Governance, 16(4), 326-341.

Cafferata, R. (2016). Darwinist connections between the systemness of social organizations and their evolution. Journal of Management \& Governance, 20(1) 19-44.

Cafferata, R. (2018). Management in adattamento. Tra razionalità economia, evoluzione e imperfezione dei sistemi. Bologna: Il Mulino.

Casciaro, T., \& Lobo, M. S. (2008). When competence is irrelevant: The role of interpersonal affect in task-related ties. Administrative Science Quarterly, 53(4) $655-684$.

Coget, J.-F., Haag, C., \& Gibson, D. E. (2011). Anger and fear in decision-making: The case of film directors on set. European Management Journal, 29(6), 476-490.

Colman, A. M. (2003). A dictionary of psychology. Oxford, UK: Oxford University Press.

Connolly, T., Ordonez, L. D., \& Coughlan, R. (1997). Regret and responsibility in the evaluation of decision outcomes. Organizational Behavior and Human Decision Processes, 70(1), 73-85. 
Cristofaro, M. (2017). Herbert Simon's bounded rationality: Its evolution in management and cross-feritilizing contribution. Journal of Management History, 23(2), 170-190.

Crossan, M. M., \& Apaydin, M. (2010). A multi-dimensional framework of organizational innovation: A systematic review of the literature. Journal of Management Studies, 47(6), 1154-1191.

Cyert, R. M., \& March, J. G. (1963). A behavioural theory of the firm. Englewood Cliffs, NJ: Prentice-Hall.

Damasio, A. R. (1994). Descartes' error: Emotion, reason, and the human brain. New York, NY: G.P. Putnam.

Davis, M. A. (2009). Understanding the relationship between mood and creativity: A meta-analysis. Organizational Behavior and Human Decision Processes, 108 $25-38$.

Davis, B. C., Hmieleski, K. M., Webb, J. W., \& Coombs, J. E. (2017). Funders' positive affective reactions to entrepreneurs' crowdfunding pitches: The influence of perceived product creativity and entrepreneurial passion. Journal of Business Venturing, 32(1), 90-106.

De Vita, L., Mari, M., \& Poggesi, S. (2013). Women entreprenurs in and from developing countries: Evidences from the literature. European Management Journal, 32(3), 451-460.

Delgado-Garcia, J. B., De la Fuente-Sabate, J. M., \& De Quevedo Puente, E. (2010). Too negative to take risks? The effect of the CEO's emotional traits on firm risk British Journal of Management, 21(2), 313-326.

Delgado-Garcia, J. B., De Quevedo Puente, E., \& Blanco Mazagatos, V. (2015). How affect relates to entrepreneurship: A systematic review of the literature and research agenda. International Journal of Management Reviews, 17(2), 191-211.

Desivilya, S. H., \& Yagil, D. D. (2005). The role of emotions in conflict management: the case of work teams. International Journal of Conflict Management, 16(1) 55-69.

Dobson, S., \& Breslin, D. (2013). An evolutionary perspective on managing the ephemeral architecture of organizational creativity. International Journal of Business Environment, 5(4), 413-429.

Edmondson, A. C., \& McManus, S. E. (2007). Methodological fit in management field research. Academy of Management Review, 32(4), 1155-1179.

Elfenbein, H. A. (2007). Emotion in organzations. The Academy of Management Annals, 1(1), 315-386.

Elsbach, K. D., \& Barr, P. S. (1999). The effects of mood on individuals' use of structured decision protocols. Organization Science, 10(2), 81-108.

Fink, G., \& Yolles, M. (2015). Collective emotion regulation in an organisatioon - a plural agency with cognition and affect. Journal of Organizational Change Management, 28(5), 832-871.

Finucane, M. L., Alhakami, A., Slovic, P., \& Johnson, S. M. (2000). The affect heuristic in judgments of risks and benefits. Journal of Behavioral Decision Making, 13 $1-17$.

Foo, M. (2009). Emotions and entrepreneurial opportunity evaluation. Entrepreneurship: Theory and Practice, 35(2), 375-393.

Forgas, J. P. (1995). Mood and judgment: The affect infusion model (AIM). Psychological Bulletin, 117(1), 39-66.

Forgas, J. P., \& George, J. (2001). Affective influences on judgments, decision making and behavior in organizations: An information processing perspective. Organizational Behavior and Human Decision Processes, 86(1), 3-34.

Fredin, A. J. (2011). The effects of anticipated regret on the whistleblowing decision. Ethics \& Behavior, 21(5), 404-427.

George, J. M. (2000). Emotions and leadership: The role of emotional intelligence. Human Relations, 53(8), 1027-1055.

Gino, F. (2015). Don't let emotions screw up your decisions. https://hbr.org/2015/05/ dont-let-emotions-screw-up-your-decisions (accessed 28 July 2018).

Gooty, J., Connelly, S., Grif, J., \& Gupta, A. (2010). Leadership, affect and emotions: A state of the science review. The Leadership Quarterly, 21(6), 979-1004.

Griffith, J. A., Connelly, S., \& Thiel, C. E. (2014). Emotion regulation and intragroup conflict: When more distracted minds prevail. International Journal of Conflict Management, 25(2), 148-170.

Guzak, J. R. (2015). Affect in ethical decision making: Mood matters. Ethics Behavior, 25(5), 386-399.

Håkonsson, D. D., Eskildsen, J. K., Argote, L. Monster, D., Burton, R. M., \& Obel, B. (2016). Exploration versus exploitation: Emotions and performance as antecedents and consequences of team decisions. Strategic Management Journal, 37(6), 985-1001.

Hambrick, D. C., \& Mason, P. A. (1984). Upper echelons: The organization as a reflection of its top managers. Academy of Management Review, 9(2), 193-206.

Hatak, I., \& Snellman, K. (2016). The influence of anticipated regret on business start-up behaviour: A research note. International Small Business Journal, 35(3), $1-12$.

Haynie, J. J. C., Flynn, B., \& Mauldin, S. (2017). Proactive personality, core self-evaluations, and engagement: The role of negative emotions. Management Decision, 55(2), 450-463.

Hillebrandt, A., \& Barclay, L. J. (2017). Comparing integral and incidental emotions: Testing insights from emotions as social information theory and attribution theory. Journal of Applied Psychology, 102(5), 732-752.

Hoelzl, E., \& Loewenstein, G. (2005). Wearing out your shoes to prevent someone else from stepping into them: Anticipated regret and social takeover in sequential decisions. Organizational Behavior and Human Decision Processes, 98(1), 15-27.

Hrebiniak, L. G., \& Joyce, W. F. (1985). Organizational adaptation: Strategic choice and environmental determinism. Administrative Science Quarterly, 30(3), 363
349

Johnson, G. \& Connelly, S. (2014). Negative emotions in informal feedback: The benefits of disappointment and drawbacks of anger. Human Relations, 67(10), $1265-1290$

Kahneman, D. (2011). Thinking, fast and slow. New York: Farrar, Straus and Giroux.

Kelly, J. R., \& Barsade, S. G. (2001). Mood and emotions in small groups and work teams. Organizational Behavior and Human Decision Processes, 86(1), 99-130.

Klaukien, A., Shepherd, D. A., \& Patzelt, H. (2013). Passion for work, nonwork-related excitement, and innovation managers' decision to exploit new product opportunities. Journal of Product Innovation Management, 30(3), 574-588.

Kligyte, V., Connelly, S., Thiel, C., \& Devenport, L. (2013). The Influence of anger, fear, and emotion regulation on ethical decision making. Human Performance, 26(4), 297-326.

Kollmann, T., Stöckmann, C., \& Kensbock, J. M. (2017). Fear of failure as a mediator of the relationship between obstacles and nascent entrepreneurial activity - an experimental approach. Journal of Business Venturing, 32(3), 280-301.

Koontz, H., O'Donnell, C., \& E Weihrich, H. (1980). Management. New York: McGrawHill.

Koskina, A., \& Keithley, D. (2010). Emotion in a call centre SME: A case study of positive emotion management. European Management Journal, 28(3), 208-219.

Kouamé, S., Oliver, D., \& Poisson-de-Haro, S. (2015). Can emotional differences be a strength? Affective diversity and management decision performance. Management Decision, 53(8), 1662-1676.

Lerner, J. S., Li, Y., Valdesolo, P., \& Kassam, K. (2013). Emotions and decision making. Annual Review of Psychology, 53(9), 1689-1699.

Lewin, A. Y., \& Volberda, H. K. (2005). The future of organization studies: Beyond the selection-adaptation debate. In H. Tsoukas, \& C. Knudsen (Eds.), The oxford handbook of organization theory (pp. 568-595). Oxford, UK: Oxford University Press.

Li, Y. (2011). Emotions and new venture judgment in China. Asia Pacific Journal of Management, 28(2), 277-298.

Lipshitz, R., \& Shulimovitz, N. (2007). Intuition and emotion in bank loan officers' credit decisions. Journal of Cognitive Engineering and Decision Making, 1(2), $212-233$.

Liu, F., \& Maitlis, S. (2014). Emotional dynamics and strategizing processes: A study of strategic conversations in top team meetings. Journal of Management Studies, 51(2), 202-231.

Loewenstein, G. F., \& Lerner, I. E. (2003). The role of affect in decision making. In R. J. Davidson, K. R. Scherer, \& H. H. Goldsmith (Eds.), Handbook of affective sciences (pp. 619-642). New York, NY: Oxford University Press.

Maitlis, S., \& Ozcelik, H. (2004). Toxic decision processes: A study of emotion and organizational decision making. Organization Science, 15(4), 375-393.

Mari, M., \& Poggesi, S. (2013). Servicescape cues and customer behavior: A systematic literature review and research agenda. Service Industries Journal, 33(2), 171-199.

Methasani, R., Gaspar, J. P., \& Barry, B. (2017). Feeling and deceiving: A review and theoretical model of emotions and deception in negotiation. Negotiation and Conflict Management Research, 10(3), 158-178.

Montes, C., Rodriguez, D., \& Serrano, G. (2012). Affective choice of conflict management styles. International Journal of Conflict Management, 23(1), 6-18.

Murmann, J. P., Aldrich, H. E., Levinthal, D., \& Winter, S. (2003). Evolutionary thought in management and organization theory at the beginning of the new Millennium. Journal of Management Inquiry, 12(1), 22-40.

O'Connell, A. (2007). Hotter heads prevail. Harvard Business Review (December).

Poggesi, S., Mari, M., \& De Vita, L. (2015). What's new in female entrepreneurship research? Answers from the literature. International Entrepreneurship and Management Journal, 12(3), 735-764.

Powell, T. C., Lovallo, D., \& Fox, C. R. (2011). Behavioral strategy. Strategic Management Journal, 32(13), 1369-1386.

Reb, J. (2008). Regret aversion and decision process quality: Effects of regret salience on decision process carefulness. Organizational Behavior and Human Decision Processes, 105(2), 169-182.

Seo, M., \& Barrett, L. F. (2007). Being emotional during decision making-good or bad? An empirical investigation. Academy of Management Journal, 50(4), 923-940.

Sibony, O., Lovallo, D., \& Powell, T. C. (2017). Behavioral strategy and the strategic decision architecture of the firm. California Management Review, 59(3), 5-21.

Simon, H. A. (1947). Administrative behavior. New York, NY: Free Press.

Simon, H. A. (1983). Reason in human affairs. Stanford, CA: Stanford University Press.

Spering, M., Wagener, D., \& Funke, J. (2005). The role of emotions in complex problem solving. Cognition and Emotion, 19(8), 1252-1261.

Staw, B. M., \& Barsade, S. G. (1993). Affect and managerial performance: A test of the sadder-but-wiser vs, happier-and-smarter hypotheses. Administrative Science Quarterly, 38(2), 304-331.

Tee, E. Y. J., Ashkanasy, N. M., \& Paulsen, N. (2013). The influence of follower mood on leader mood and task performance: An affective, follower-centric perspective of leadership. The Leadership Quarterly, 24(4), 396-515.

Thaler, R. H., \& Sunstein, C. R. (2008). Nudge: Improving decisions about health, wealth and happiness. New Haven, CT: Yale University Press.

Thiel, C. E., Connelly, S., \& Griffith, J. A. (2012). Leadership and emotion management for complex tasks: Different emotions, different strategies. The Leadership Quarterly, 23(3), 517-533.

Tranfield, D., Denyer, D., \& Smart, P. (2003). Towards a methodology for developing evidence-informed management knowledge by means of systematic review. British Journal of Management, 14(3), 207-222. 
Uli, V. (2018). Co-evolutionary dynamics in the music industry. International Journal of Organizational Analysis, 26(2), 296-311.

Visser, V. A., Knippenberg, D., Kleef, G. A., \& Wisse, B. (2013). How leader displays of happiness and sadness influence follower performance: Emotional contagion and creative versus analytical performance. The Leadership Quarterly, 24(1), $172-188$.

Von Koskull, C., Strandvik, T., \& Tronvoll, B. (2016). Emotional strategizing in service innovation. Management Decision, 54(2), 270-287.

Walker, E., Hernandez, A. V., \& Kattan, M. W. (2008). Meta-analysis: Its strengths and limitations. Cleveland Clinical Journal of Medicine, 75(6), 431-439.

Walsh, G. (2018). Service employees' naturally felt emotions: Do they matter? European Management Journal. https://doi.org/10.1016/j.emj.2018.06.008. forthcoming.

Weick, K. E. (1969). The social psychology of organizing. Reading, MA: AddisonWesley.

Welpe, I. M., Sporrle, M., Grichnik, D., Michl, T., \& Audretsch, D. B. (2012). Emotions and opportunities: The interplay of opportunity evaluation, fear, joy, and anger as antecedent of entreprenurial explanation. Entreprenurship Theory \& Practice, 36(1), 69-96.

Williams, M., \& Emich, K. J. (2014). The experience of failed humor: Implications for interpersonal affect regulation. Journal of Business and Psychology, 29(4), $651-668$.
Winterich, P. K., Morales, A. C., \& Mittal, V. (2015). Disgusted or happy, it is not so bad: Emotional mini-max in unethical judgments. Jornal of Business Ethics, 130(2), 343-360.

Wolf, E. B., Lee, J. J., Sah, S., \& Brooks, A. W. (2016). Managing perceptions of distress at work: Reframing emotion as passion. Organizational Behavior and Human Decision Processes, 137, 1-12.

Yang, M.-Y., Cheng, F.-C., \& Chuang, A. (2015). The role of affects in conflict frames and conflict management. International Journal of Conflict Management, 26(4).

Yang, I., \& Kelly, A. (2016). The positive outcomes of 'socially sharing negative emotions' in workteams: A conceptual exploration. European Management Journal, 34(2), 172-181.

Zeelenberg, M. (1998). Reconsidering the relation between regret and responsibility. Organizational Behavior and Human Decision Processes, 74(3), 254-272.

Zeelenberg, M., van Dijk, W. W., van der Pligt, J., Manstead, A. S. R., van Empelen, P., \& Reinderman, D. (1998). Emotional reactions to the outcomes of decisions: The role of counterfactual thought in the experience of regret and disappointment. Organizational Behavior and Human Decision Processes, 75(2), 117-141.

Zhang, J., Chiu, R., \& Wei, L.-Q. (2009). On whistleblowing judgment and intention. The role of positive mood and organizational ethical culture. Journal of Managerial Psychology, 24(7), 627-649. 